\title{
PERKEMBANGAN TATA GUNA LAHAN DITINJAU DARI HISTORIS KELELAWAR SEBAGAI NILAI SIMBOL DI KECAMATAN LALABATA
}

\author{
Agusanjaya1, Nursyam AS ${ }^{2}$, Fadhil Surur ${ }^{3 *}$ \\ Jurusan Teknik Perencanaan Wilayah dan Kota, Fakultas Sains dan Teknologi, UIN Alauddin Makassar, Makassar, Indonesia \\ *Email Koresponden: fadhil.surur@uin-alauddin.ac.id \\ Diterima: 11-04-2020, Revisi: 03-05-2020, Disetujui 30-05-2020 \\ (C)2020 Program Studi Pendidikan Geografi, FISE, Universitas Hamzanwadi
}

\begin{abstract}
Abstrak Keberadaan kelelawar di kawasan perkotaan Kabupaten Soppeng tidak hanya menyimpan misteri, akan tetapi telah menjadi keunikan di daerah ini. Mereka tetap eksis di tengah perkembangan kota yang semakin pesat. Penelitian ini bertujuan untuk mengetahui pengaruh habitat kelelawar pada perkembangan tata guna lahan dan arahan perkembangan tata guna lahan dalam menjaga keberlanjutan nilai historis kelelawar. Metode analisis data yang digunakan yaitu analisis deskriptif dan analisis regresi linier. Hasil penelitian menunjukkan bahwa perkembangan perkotaan membentuk pola linier yang mengikuti arah jalan sehingga perkotaan tidak terpusat di perkotaan Watansoppeng. Hasil analisis regresi linier menunjukkan penduduk berpengaruh terhadap perkembangan tata guna lahan di Kecamatan Lalabata Kabupaten Soppeng, penduduk lebih dominan membangun ke luar dari pusat kota karena adanya habitat kelelawar yang ingin mereka lestarikan.
\end{abstract}

Kata kunci: tata guna lahan, kota, kelelawar

\begin{abstract}
The existence of bats in the urban area of Soppeng Regency not only had a mystery, but also was a unique characteristic in that area. The bats still exist even the city was developed rapidly. This study was aimed to study the effect of bat habitat on land use development and to understand the direction of land use development in maintaing the sustainability of the bat's historical value. Desctiptive analysis and linear regression methods were used in this research. The results showed that the development of the city had linear pattern which follows the direction of the road so that the city was not centralized in Watansoppeng. The linear regression result showed that the population affect the development of land use in the District of Lalabata, Soppeng Regency. The population was more dominant to build outside the city in order to converse the habitat of bats.
\end{abstract}

Keywords: land use, city, bat

\section{PENDAHULUAN}

Lahan merupakan wadah dari aktivitas yang memiliki nilai ekonomi penting dalam pembentukan permukiman dengan aktivitas kompleks. Sementara itu lahan disebut sebagai produk karena kegiatan perencanaan menghasilkan set tata ruang dan pengelolaannya, di mana lahan yang tertata adalah bagian di dalamnya. Lahan harus dijaga dan dipergunakan untuk kepentingan masyarakat luas dan agar terciptanya keserasian dan keseimbangan lahan sehingga dapat melestarikan lingkungan hidup. Selain itu lahan sangat penting karena merupakan input sekaligus produk dari proses perencanaan. Disebut input karena lahan merupakan modal dasar pembentukan ruang (Hasni, 2006). Urbanitas berada di lingkungan binaan manusia yang memiliki struktur dan wujud yang bisa dan layak ditinggali. Oleh karenanya, proses yang mempertautkan sekelompok manusia dan tempat tinggalnya melalui aktivitas sosial ekonomi akan dapat dicapai melalui kegiatan membangun dan membina kehidupan bermasyarakat (Nugroho, 2009).

Untuk menjaga keseimbangan lahan perlu adanya tata guna lahan yang bertujuan mengatur penggunaan lahan agar dapat dimanfaatkan sebesar-besarnya untuk kepentingan masyarakat luas. Tata guna lahan sendiri memiliki pengertian sebagai suatu upaya dalam merencanakan penggunaan lahan dalam suatu kawasan yang meliputi pembagian wilayah untuk pengkhususan fungsi-fungsi tertentu, misalnya permukiman, industri, perdagangan, dan lain-lain. Tata guna lahan berfungsi sebagai pengarah 
penggunaan lahan dengan kebijakan dan program tata keruangan untuk memperoleh manfaat total sebaik-baiknya secara berkelanjutan dari daya dukung tiap bagian lahan yang disediakan. Tata guna lahan membimbing pembangunan wilayah yang bertujuan menumbuhkan dan mengembangkan lahan. Dengan kata lain tata guna lahan adalah salah satu faktor penentu dalam merencanakan suatu wilayah sesuai dengan karakteristik dan kemampuan lahan itu sendiri (Hasni, 2016). Hal ini senada dengan pengertian lingkungan hidup, yaitu sistem yang merupakan kesatuan ruang dengan semua benda, daya, keadaan, dan makhluk hidup termasuk manusia dan perilakunya yang menentukan perikehidupan serta kesejahteraan manusia dan makhluk hidup lainnya. Atau bisa juga dikatakan sebagai suatu sistem kehidupan dimana terdapat campur tangan manusia terhadap tatanan ekosistem (Hasni, 2016). Ciri-ciri lingkungan yang dinilai masyarakat sesuai dengan karakter kota, oleh masyarakat juga dinilai sebagai memiliki profil makna yang positif, termasuk berbagai elemen alam dan buatan. Lingkungan buatan yang mendukung karakter kota salah satunya dengan karakter historisnya (Amuiza \& Ernawati, 2014). Perubahan-perubahan tata ruang di perkotaan dapat ditinjau dari perubahan tata guna lahan yang memiliki karakteristik tertentu dan memengaruhi setiap warga serta kehadiran investor atau pengembang yang melakukan pembangunan gedung, fasilitas umum, ruang publik, dan lainnya (Aminah, 2015).

Dalam menentukan fungsi kawasan tidak hanya ditekankan pada konfigurasi massa fisik tetapi juga harus memperhatikan integrasi antara aspek fisik morfologi ruang dengan masyarakat atau manusia yang tinggal di kawasan tersebut. Morfologi kota secara sederhana dapat diartikan sebagai bentukbentuk fisik kota dengan diketahui secara struktural, fungsional dan visual (Litiloly, 2019). Sebagaimana tempat mempunyai masa lalu (lingkage story), tempat juga harus berkembang pada masa berikutnya. Morfologi kota terbentuk melalui proses yang panjang, setiap perubahan bentuk kawasan secara morfologis dapat memberikan arti serta manfaat yang sangat berharga bagi penanganan perkembangan suatu kawasan kota (Tallo, Pratiwi, \& Astutik, 2014). Artinya nilai sejarah di suatu tempat atau kawasan sangat penting di jadikan suatu pertimbangan untuk menentukan fungsi kawasan, mengingat bahwa suatu ruang (space) akan menjadi tempat (place) apabila diberikan makna kontekstual dari muatan budaya atau potensi muatan lokalnya (Hasni, 2006). Dalam tataran kota, masyarakat lama dengan karakter lingkungannya masih tampak keterikatan (spirit of place) yang tinggi, dengan mempertahankan keberadaan sistem kekerabatan dalam lingkungan (Wulandari \& Aulia, 2018).

Pertumbuhan penduduk yang pesat serta bertambahnya tuntutan kebutuhan masyarakat akan lahan, seringkali mengakibatkan benturan kepentingan atas penggunaan lahan serta terjadinya ketidaksesuaian antara penggunaan lahan dengan rencana peruntukannya (Khadiyato, 2005 dalam Eko \& Rahayu, 2012). Di negara kita kegiatan tata guna lahan oleh negara (pemerintah) bukan berlandaskan konsepsi komunis yang mengusung pemikiran bahwa negara yang mengatur peruntukan, penyediaan, dan kegunaan lahan secara mutlak karena negara adalah pemilik lahan di negara tersebut. Negara kita juga tidak berlandaskan konsepsi liberalisme yang beranggapan bahwa negara harus ikut campur tangan untuk peruntukan penggunaan lahan dan tidak membiarkan kemauan dari masing - masing golongan, melainkan ada campur tangan pemerintah (dianggap intervensi). Untuk mengukur sejauh mana intervensi itu tergantung pada pandangan politik dan political will pemerintah yang berkuasa. Akan tetapi di negara kita, kegiatan tata guna lahan berlandaskan konsepsi hukum adat karena sejak dulu hukum adat tidak membiarkan peruntukan dan penggunaan tanahnya berlandaskan pada kepentingan pribadi perseorangan, misalnya untuk usaha pemukiman atau untuk hutan. Peraturan ini merupakan peraturan yang tidak tertulis, akan tetapi larangan tersebut berupa peringatan. Ide tersebut tertuang dalam UUD dalam pasal 33 ayat 3 tahun 1945 yang berbunyi " bumi, air, dan kekayaan alam yang terkandung di dalamnya adalah karunia dari Tuhan Yang Maha Esa, dimanfaatkan sebesar-besarnya untuk kemakmuran rakyat". Selanjutnya Undang-Undang Pokok Agraria mejabarkan bahwa dalam rangka mewujudkan pemanfaatan lahan sebesar-besarnya bagi kemakmuran rakyat, negara sebagai organisasi kekuasaan bangsa Indonesia diberi wewenang untuk mengatur dan menyelenggarakan peruntukan penggunaan lahan dan pemeliharaannya, menentukan hak-hak yang dapat dipunyai atas hak tanah, menentukan hukum antara pemilik dan penggunaan atas lahannya. Dalam artian, negara bermaksud untuk mewujudkan pembanguan yang terintegrasi dengan peraturan hukum yang berlaku untuk kepentingan masyarakat (Hasni, 2006). 
Kabupaten Soppeng adalah salah satu kabupaten yang terdapat di Sulawesi Selatan dengan Ibukota Watansoppeng dan terletak pada ketinggian 120 mdpl. Kawasan perkotaan Watansoppeng menyimpan keunikan dan berbeda dengan kota-kota lain karena terdapat sekelompok habitat kelelawar yang tinggal di pusat perkotaan Watansoppeng. Selain keunikannya, habitat kelelawar yang terdapat di kawasan perkotaan Watansoppeng mempunyai nilai historis bagi masyarakat di Kabupaten Soppeng. Kepercayaan yang berkembang di kalangan masyarakat mengatakan bahwa adanya larangan menebang atau mengganggu habitat kelelawar yang terdapat di pusat pekotaan Watansoppeng. Hal ini karena dipercaya sebagai pertanda bahwa adanya bahaya yang akan datang. Keberadaan kelelawar atau yang biasa di sebut juga sebagai kalong tersebut dijamin pemerintah Kabupaten Soppeng sesuai Peraturan Daerah (Perda) No. 66 Tahun 2006, Bab V pasal 6 ayat 1-4, pasal 7, dan pasal 8 yang berbunyi “ barangsiapa mengganggu apalagi menebang pohon asam tempat bergelantungan habitat kelelawar akan dikenakan denda atau kurungan penjara". Demi melestarikan keberadaan kelelawar dan pohon asam yang bersejarah di tempat tersebut, Pemda setempat hanya memangkas tangkai pohon asam yang menjulur ke arah jalan raya, selebihnya untuk kelelawar. Keberadaan habitat kelelawar di Soppeng telah beasosiasi dengan keberadaan Ruang Terbuka Hijau (RTH) sebagai habitat mereka. RTH berperan dalam menjaga keseimbangan antara lingkungan alam dan lingkungan binaan yang berguna untuk kepentingan masyarakat, serta meningkatkan keserasian lingkungan perkotaan (Wahrudin et al., 2019).

Keberadaan kelelawar yang ada di kawasan perkotaan Watansoppeng tersebut sudah ada semenjak raja Soppeng pertama (Latemmamala) ratusan tahun yang lalu. Dari cerita yang berkembang di kalangan masyarakat Soppeng, raja melakukan perjanjian dengan Kelelawar yang tinggal di jantung kota Soppeng tersebut. Dalam perjanjian tersebut mereka tidak boleh mengambil atau memakan buahbuahan masyarakat. Kedua, mereka boleh berdiam di kota akan tetapi hanya di pohon asam. Terakhir, raja meminta kepada mereka (kelelawar) jika akan terjadi suatu bencana, musibah, atau sesuatu yang menuntut rakyat untuk bersiap-siap, mereka diharapkan segera memberitahu rakyat melalui tanda-tanda alam yang mereka isyaratkan. Perjanjian terakhir ini kerap ditunjukkan dengan perilaku kelelawar yang menghilang minimal 24 jam dari pohonnya. Hingga kini perjanjian tersebut masih terjaga dan kelelawar pun masih sangat banyak di pusat kota Soppeng, tepatnya di Kecamatan Lalabata. Mitos lain yang menyeruak ke permukaan juga mengatakan bahwa bagi mereka yang belum mendapat jodoh, apabila terkena kotoran kalong dapat menjadi pertanda bahwa seseorang terebut akan mendapat jodoh dari kota Soppeng atau menjadi penduduk tetap di Soppeng.

Bagi masyarakat Soppeng sendiri, kehadiran kelelawar ini menjadi endemic tersendiri sekaligus sebagai penjaga kota. Selain sebagai penjaga, kelelawar-kelelawar tersebut juga dapat menjadi pengirim pesan tersirat tentang kemungkinan hal-hal yang akan terjadi dengan segala hukumnya. Dengan adanya perlindungan habitat kelelawar yang berada di kawasan perkotaan Watansoppeng integritas perkembangan yang cukup pesat sangat mempengaruhi kebijakan perkembangan ruang fisik perkotaan, dalam hal ini adalah penataan tata guna lahan. Kebijakan pembangunan dalam kawasan perkotaan akan menjadi pertimbangan yang penting oleh keberadaan kelelawar. Akibatnya, pola pembangunan atas tata guna lahan harus mengikuti keberadaan kelelawar. Di samping itu, faktor fisik lingkungan kawasan perkotaan yang bertopografi turut pula menentukan arah perkembangan perkotaan, sehingga kawasan perkotaan tidak dapat diwujudkan dengan terpusat. Dengan adanya keyakinan yang berkembang di tengah masyarakat Kabupaten Soppeng, dapat diketahui bahwa kelelawar merupakan salah satu faktor yang mempengaruhi perkembangan tata guna lahan yang berpusat di Kecamatan Lalabata Kabupaten Soppeng. Terutama baik disebabkan karena keunikannya maupun karena nilai historis dari kelelawar itu sendiri. Tujuan dari penelitian ini adalah mengetahui pengaruh habitat kelelawar dalam pembangunan dan perkembangan tata guna lahan dan menyusun arahan pengembangan tata guna lahan dalam menjaga keberlanjutan nilai historis dari kelelawar.

\section{METODE PENELITIAN}

Lokasi penelitian ini berada di Kecamatan Lalabata Kabupaten Soppeng, tepatnya di kawasan perkotaan Watansoppeng. Penelitian dibatasi pada kawasan pusat kota Watansoppeng merujuk pada ekosistem kelelawar yang berada pada pusat kota tersebut. Penetapan lokasi tersebut didasarkan atas 
pertimbangan bahwa di kawasan pusat kota tempat bermukimnya ekosistem kelelawar perlu di perhatikan dengan cermat. Terutama dalam perkembangan tata guna lahan ditinjau dari historis kelelawar sebagai nilai simbol di daerah tersebut. Waktu penelitian dilakukan selama 6 bulan yaitu mulai 30 Februari sampai bulan Agustus 2019.

Jenis data terdiri dari data kuantitatif (berbentuk angka) dan data kualitatif (deksripsi). Data kuantitatif yang dikumpulkan berupa data perkembangan tata guna lahan, luas wilayah demografi dan lainnya, sedangkan data kualitatif berupa deskripsi kondisi lokasi penelitian secara umum. Sumber data terdiri dari data primer dan data sekunder. Data primer berupa data yang diperoleh dari pengamatan langsung di lapangan terkait kebutuhan penelitian, sedangkan data sekunder diperoleh dari instansi terkait seperti kantor kelurahan, kantor kecamatan, kantor Dinas Kebudayaan, BPS Kabupaten Soppeng, kantor Bappeda dan kantor Dinas PU. Metode pengumpulan data yang digunakan dalam penelitian ini yakni observasi, wawancara (interview) dan kepustakaan.

Populasi adalah keseluruhan subjek penelitian atau jumlah keseluruhan dari unit analisis dalam penelitian dan merupakan unsur-unsur keperluan yang memliki satu atau beberapa ciri/karakteristik tertentu yang ditetapkan oleh peneliti untuk dipelajari dan kemudian ditarik kesimpulannya (Arikunto, 2002). Adapun yang menjadi populasi adalah masyarakat yang tinggal dan menetap di Kecamatan Lalabata. Populasi ini mengacu kepada Jumlah penduduk di Kecamatan Lalabata pada tahun 2018 yakni sebanyak 44.828 jiwa. Data jumlah Kepala Keluarga didapatkan dari data Badan Pusat Statistik (BPS) Kecamatan Lalabata. Populasi ini nantinya akan menjadi acuan dalam menentukan jumlah sampel.

Sampel adalah jumlah anggota yang dipilih atau diambil dari suatu populasi, yang diharapkan mampu mewakili atau menggambarkan ciri-ciri keberadaan populasi sebenarnya. Teknik penarikan sampel didasarkan pada lingkup pembahasan dan data yang dibutuhkan untuk penelitian. Maka penarikan sampel dalam penelitian ini dilakukan secara acak, yaitu sampel yang dapat mewakili populasi disesuaikan dengan kebutuhan data dalam penelitian dengan ciri-ciri yang ada pada lokasi dan keberadaannya dianggap baik dan berkualitas atau mampu menggambarkan karakteristik atau profil keberadaan populasi sebenarnya. Pengambilan sampel dilakukan secara simple random sampling. Rumus pengambilan jumlah sampel yang akan digunakan pada penelitian ini adalah sebagai berikut

$$
n=\frac{N}{N(d)^{2}+1}
$$

Keterangan:

$\mathrm{n}=$ Jumlah Sampel yang diambil

$\mathrm{N}=$ Jumlah Populasi

$\mathrm{d}=$ Derajat Kebebasan $(10-15 \%)$

Dengan jumlah populasi sebanyak 44.828 serta menggunakan derajat kebebasan 10\%, maka di peroleh jumlah sampel yang digunakan pada penelitian yakni 99,7 yang dibulatkan menjadi 100 responden. Metode analisis terdiri dari analisis deskriptif, merupakan pengumpulan informasi status suatu gejala yang ada tentang tata guna lahan terhadap historis dengan melihat perbandingan perkembangan tata guna lahan di lokasi penelitian dari tahun-tahun sebelumnya sampai sekarang. Selanjutnya analisis regresi linier, merupakan analisis yang digunakan untuk mengetahui pengaruh antara satu atau beberapa variabel terhadap satu buah variabel, dengan rumus sebagai berikut:

$$
\mathrm{Y}=\mathrm{a}+\mathrm{bX}
$$

Keterangan:

Y : Variabel terikat (Dependent)

$\mathrm{X} \quad$ : Variabel bebas (Indepensent)

a : Konstanta

b : Kofisien regresi; besaran respon yang ditimbulkan oleh variable bebas 


\section{TEMUAN DAN PEMBAHASAN}

Kecamatan Lalabata merupakan salah satu dari 8 kecamatan yang ada di Kabupaten Soppeng. Kecamatan Lalabata memiliki luas wilayah sebesar $278 \mathrm{Km}^{2}$ atau 18,53\% dari luas Kabupaten Soppeng. Kecamatan ini terbagi atas 10 kelurahan/desa. Desa yang paling luas adalah Desa Umpungeng dengan luas wilayah $85 \mathrm{Km}^{2}$ atau 30,57\% dari luas Kecamatan Lalabata. Adapun di kelurahan/desa dengan luas wilayah yang paling kecil yaitu Kelurahan Lapajung dengan luas $5 \mathrm{Km}^{2}$ atau 1,80\% dari luas wilayah Kecamatan Lalabata. Kecamatan Lalabata memiliki batas administrasi sebelah utara berbatasan dengan Kecamatan Donri-Donri, sebelah Timur berbatasan dengan Kecamatan Liliriaja, sebelah Selatan berbatasan dengan Kecamatan Marioriwawo dan sebelah Barat berbatasan dengan Kabupaten Barru. Lokasi studi objek penelitian terletak di kawasan perkotaan Watansoppeng, Kecamatan Lalabata, Kabupaten Soppeng dengan luas 28,26 ha. Di kawasan objek penelitian ini terdapat 3 kelurahan/desa yaitu Kelurahan Botto, Kelurahan Bila, dan Kelurahan Lemba. Adapun batas wilayah administrasi lokasi penelitian yang terletak di Kawasan perkotaan Watansoppeng berbatasan dengan Kelurahan Lapajjung sebelah utara, Kelurahan Lemba sebelah timur, Kelurahan Botto sebelah selatan dan Kelurahan Bila sebelah barat.

Berdasarkan data yang diperoleh dari 100 responden, tentang pengaruh beberapa variabel terhadap perkembangan tata guna lahan di tinjau dari historis kelelawar sebagai nilai simbol di kawasan penelitian, maka dapat dijelaskan sebagai berikut:

1) Aspek fisik yang dilibatkan dalam penelitian terdiri dari hidrologi, klimatologi, geologi, jenis tanah, dan kemiringan lereng. Dari hasil penilaian 100 responden untuk tingkat pengaruh setiap aspek fisik, diperoleh data yang memiliki persentase tertinggi yaitu hidrologi dan kemiringan lereng dinilai sangat berpengaruh dengan tingkat persentase masing-masing 44\% dan 49\%. Aspek klimatologi dinilai berpengaruh dengan tingkat persentase $57 \%$. Sedangkan geologi dan jenis tanah dinilai cukup berpengaruh dengan tingkat persentase masing-masing 37\% dan 53\%.

2) Dari data yang terkait pandangan penduduk terhadap habitat kelelawar yang terdapat di perkotaan Watansoppeng maka dapat diketahi bahwa keberadaan kelelawar terhadap aktivitas masyarakat tidak berpengaruh dengan persentase sebesar $68 \%$. Pengaruh kelelawar terhadap tradisi dan budaya dinilai sangat baik dengan persentase sebesar $59 \%$. Terkait kegiatan pembangunan di perkotaan Watansoppeng, masyarakat tidak membangun di sekitar habitat kelelawar karena menghargai nilai (historis) atau sejarah di kawasan tersebut dengan persentase sebesar $52 \%$. Pengaruh habitat kelelawar terhadap tata guna lahan di perkotaan Watansoppeng dinilai sangat berpengaruh dengan persentase $55 \%$. Masyarakat yang kurang berminat untuk memiliki lahan di sekitar kawasan tersebut sebanyak $41 \%$.

3) Dari data aksesibilitas yang diperoleh dapat dipahami bahwa untuk tingkat pencapaian dinilai sangat mudah yaitu sebesar $46 \%$ dari 100 responden. Untuk jarak tempuh dinilai dekat sebesar $41 \%$ dari 100 responden. Sedangkan lama jarak tempuh dinilai sebentar dengan persentase $66 \%$ dari 100 responden.

4) Dari data sarana dan prasarana dapat dilihat bahwa fasilitas umum tersedia dengan persentase sebanyak $39 \%$. Fasilitas sosial dinilai tersedia dengan persentase sebanyak $56 \%$. Sedangkan kondisi jalan dinilai bagus dengan persentase sebanyak $56 \%$.

5) Dari data daya dukung lahan diperoleh kualitas lingkungan nilai bagus dengan persentase sebesar 51 $\%$ dan status lahan dinilai milik negara dengan pesentase $34 \%$.

6) Sedangkan untuk indikator faktor diperoleh data persentase tertinggi pada masing-masing aspek yang diperoleh pada pengaruh keberadaan habitat kelelawar di perkotaan Watansoppeng. Adapun untuk faktor penyebab pembangunan di luar perkotaan, sebesar 36\% responden menyatakan penyebabnya adalah adanya habitat kelelawar. Untuk faktor keinginan membangun di sekitar habitat kelelawar, sebesar 36\% responden menyatakan tidak berminat. Faktor keinginan membangun di sekitar habitat kelelawar, sebesar 39\% responden menyatakan penyebabnya adalah karena dekat dengan habitat kelelawar yang merupakan ikon kota Watansoppeng. Sedangkan Penyebab tidak ingin membangun di sekitar habitat kelelawar, sebesar 30\% responden menyatakan karena dilarang oleh pemerintah setempat. 
Analisis regresi merupakan studi ketergantungan satu atau lebih $\mathrm{X}$ (variabel bebas) terhadap $\mathrm{Y}$ (variabel terikat), dengan maksud untuk meramalkan nilai $Y$. Tujuan analisis regresi adalah mendapatkan pola hubungan secara matematis antara $\mathrm{X}$ dan $\mathrm{Y}$, mengetahui besarnya pengaruh variabel $\mathrm{X}$ terhadap $\mathrm{Y}$, dan memprediksi $Y$ jika nilai X diketahui. Sehingga dalam suatu persamaan regresi terdapat dua macam variabel, yaitu dependent variabel dan independent. Berikut adalah hasil rekapitulasi data dari responden untuk mengetahui perkembangan tata guna lahan ditinjau dari historis kelelawar sebagai nilai simbol di Kecamatan Lalabata Kabupaten Soppeng:

Tabel 1. Hasil rekapitulasi data aspek fisik

\begin{tabular}{lccccc}
\hline & $\mathbf{X}$ & $\mathbf{Y}$ & $\mathbf{X Y}$ & $\mathbf{x}^{\mathbf{2}}$ & $\mathbf{Y}^{\mathbf{2}}$ \\
\hline $\mathrm{X} 1$ & 336 & 298 & 1017 & 1214 & 965 \\
$\mathrm{X} 2$ & 405 & 298 & 1228 & 1679 & 965 \\
$\mathrm{X} 3$ & 320 & 298 & 959 & 1097 & 965 \\
$\mathrm{X} 4$ & 345 & 298 & 1034 & 1261 & 965 \\
$\mathrm{X} 5$ & 350 & 298 & 1036 & 1316 & 965 \\
\hline
\end{tabular}

Sumber: Data Primer, 2019.

Berikut hasil uji regresi sederhana untuk melihat pengaruh variabel (independet) bebas terhadap variabel (dependent) terikat. Pengambilan keputusan dalam uji regresi sederhana didasarkan pada tingkat signifikansi sebesar $5 \%$ atau 0,05 .

Tabel 2. Hasil analisis regresi

\begin{tabular}{lccccc}
\hline \multicolumn{7}{c}{ Coefficients $^{\mathbf{a}}$} \\
\hline & \multicolumn{2}{c}{ Unstandardized Coefficients } & $\begin{array}{c}\text { Standardized } \\
\text { Coefficients }\end{array}$ & & \\
\cline { 2 - 4 } Model & $\mathrm{B}$ & Std. Error & Beta & $\mathrm{t}$ & Sig. \\
\hline (Constant) & 1.323 & .754 & & 1.755 & .083 \\
$\mathrm{X} 1$ & -.043 & .117 & -.038 & -.365 & .716 \\
$\mathrm{X} 2$ & .510 & .125 & .430 & 4.073 & .000 \\
$\mathrm{X} 3$ & .070 & .116 & .066 & .605 & .546 \\
$\mathrm{X} 4$ & .018 & .127 & .018 & .145 & .885 \\
$\mathrm{X} 5$ & -.156 & .109 & -.159 & -1.434 & .155 \\
\hline
\end{tabular}

Sumber: Hasil olahan data primer, 2019.

Dasar dari pengambilan keputusan jika nilai signifikan $<$ dari 0,05 artinya variabel $\mathrm{X}$ berpengaruh terhadap variabel $\mathrm{Y}$ sedangkan Jika nilai signifikan $>$ dari 0,05 artinya variabel $\mathrm{X}$ tidak berpengaruh terhadap variabel Y.

Tabel 3. Hasil rekepitulasi data perkembangan tata guna lahan ditinjau dari kelelawar sebagai nilai simbol

\begin{tabular}{|c|c|c|}
\hline No & Variabel & Keterangan \\
\hline 1 & Aspek Fisik & Tidak berpengaruh \\
\hline 2 & Penduduk & Berpengaruh \\
\hline 3 & Aksesibilitas & Tidak berpengaruh \\
\hline 4 & Sarana dan Prasarana & Tidak berpengaruh \\
\hline 5 & Daya Dukung Lahan & Tidak berpengaruh \\
\hline
\end{tabular}

Sumber: Hasil olahan data primer, 2019.

Dari hasil analisis dapat diketahui bahwa variabel yang berpengaruh pada perkembangan tata guna lahan ditinjau dari kelelawar terhadap nilai simbol di Kecamatan Lalabata Kabupaten Soppeng sebagai berikut:

1) Aspek fisik

Diperoleh dari nilai sig $716>0,05$ maka variabel aspek fisik tidak berpengaruh signifikan terhadap perkembangan tata guna lahan ditinjau dari historis kelelawar sebagi nilai simbol di Kecamatan Lalabata Kabupaten Soppeng. Sejalan dengan hasil analisis di atas, teori seleksi habitat mengatakan bahwa seleksi habitat merupakan proses atau tingkah laku di mana satwa menyeleksi atau memilih suatu habitat sebagai tempatnya untuk bertahan hidup (Wirakusumah, 2003). Seleksi habitat juga merupakan proses satwa untuk memilih komponen habitat yang mereka inginkan 
(Susanto, 2000). Sejalan dengan teori tersebut maka aspek fisik suatu wilayah tidak selamanya merupakan faktor penentu keberadaan habitat kelelawar. Namun pada umumnya kelelawar memiliki karakter tersendiri untuk dapat hidup di habitat gua. Suhu udara, kelembaban udara, intensitas cahaya dan kecepatan angin merupakan faktor penting bagi keberlangsungan hidup populasi kelelawar di dalam gua atau ruang yang gelap (Piter et al., 2015).

2) Penduduk

Dari hasil analisis data diperoleh nilai sig $000<0,05$ maka variabel penduduk berpengaruh signifikan terhadap perkembangan tata guna lahan ditinjau dari historis kelelawar sebagi nilai simbol di Kecamatan Lalabata Kabupaten Soppeng. Dilihat dari hasil analisis di lokasi penelitian, penduduk lebih dominan memilih untuk tidak membangun di sekitar habitat kelelawar yang ada di perkotaan Watansoppeng karena adanya habitat kelelawar sebagi nilai simbol dan sebagai icon perkotaan Watansoppeng. Penduduk juga masih menghargai nilai-nilai adat istiadat, budaya, dan kepercayaan yang dianut turun temurun oleh masyarakat. Disamping itu di sekitar habitat kelelawar juga terdapat bangunan bersejarah sehingga masyarakat menilai harus melestarikan kawasan tersebut dan dominan memilih untuk tidak melakukan pembangunan di sekitar habitat kelelawar tersebut. Dari variabel penduduk terdapat dua jenis penduduk yaitu penduduk lokal dan penduduk pendatang.

Penduduk lokal yang dominan tidak memilih membangun ataupun bermukim di sekitar habitat kelelawar disebabkan karena adanya kekayakinan, adat istiadat, dan kebudayaan yang secara turun temurun yang dijaga agar kebudayaan tersebut tidak luntur oleh zaman. Penduduk pendatang yang dominan memilih untuh tidak membangun atau bermukim disekitar habitat kelelawar disebabkan karena adanya aturan pemerintah melalui peraturan daerah (Perda) Kabupaten Soppeng No. 66 tahun 2006 Bab V Pasal 6 ayat 1-4, pasal 7, pasal 8 yang berbunyi "barang siapa mengganggu atau menebang pohon temapt habitat kelelawar akan di kenakan denda atau kurungan penjara".

Peraturan Daerah Kabupaten Soppeng tahun 2012 juga menegaskan pada paragraf 7 tentang kawasan lindung lainnya dalam pasal 53 ayat 1 huruf $g$ meliputi kawasan perlindungan satwa kelelawar. Ketentuan umum peraturan zonasi untuk kawasan perlindungan satwa kelelawar sebagaimana ayat 1 meliputi kegiatan yang diperbolehkan yaitu pariwisata, pendirian bangunan atau fasilitas penunjang kawasan pelestarian satwa, penelitian, pendidikan, pengembangan ilmu pengetahuan, serta pengembangbiakan atau pelestarian satwa. Kegiatan yang diperbolehkan dengan syarat meliputi kegiatan sebagaimana yang dimaksud pada ayat 1 yang tidak mengganggu pelestarian satwa. Kegiatan yang tidak diperbolehkan meliputi kegiatan perburuan satwa yang tidak ditetapkan sebagai buruan dan mengganggu fungsi kawasan.

Dari uraian penduduk tersebut baik penduduk lokal maupun pendatang dominan lebih memilih tidak membangun di sekitar habitat kelelawar karena adanya kebudayaan, kepercayaan dan adat istiadat yang di wariskan turun temurun oleh generasi sebelumnya kepda generasi pelanjut agar menjaga kebudayaan tersebut. Selain itu juga ditegaskan pula oleh peraturan daerah (Perda) agar tidak membangun kecuali sarana dan prasarana penunjang di sekitar habitat kelelawar tersebut agar tidak mengganggu fungsi kawasan habitat kelelawar. Dalam hal ini sejalan dengan pemahaman Roger Trancik dengan "Place Theory"-nya (1986), dalam buku Finding Lost Space mengungkapkan pengertian "Place Theory" yaitu, pemahaman tentang kultur dan karakteristik suatu daerah yang ada dan telah menjadi ciri khas untuk dipakai sebagai salah satu bahan pertimbangan dalam menciptakan lingkungan, agar penghuni tidak merasa asing dalam lingkungan tersebut serta memelihara ekosistem tertentu. Dalam konteks tersebut menjadi bukti bahwa manusia seharusnya berkepentingan untuk memelihara keberlangsungan eksistensi bumi, karena manusia mau tidak mau kehidupannya tergantung kepada sejauh mana bumi itu memiliki kemampuan menyediakan sarana dan prasarana bagi kehidupan manusia (Yusuf, 2017).

3) Aksesibilitas

Diperoleh dari nilai sig $546>0,05$ maka variabel aspek fisik tidak berpengaruh signifikan terhadap perkembangan tata guna lahan di tinjau dari historis kelelawar sebagi nilai simbol di Kecamatan Lalabata Kabupaten Soppeng. Karakteristik sistem transportasi ditentukan oleh aksesibilitas yang memberikan pengaruh pada beberapa lokasi kegiatan atau tata guna lahan. Lokasi 
kegiatan juga memberikan pengaruh terhadap pola perjalanan untuk melakukan kegiatan sehari-hari. Hal ini "tidak sejalan" dengan hasil penelitian di mana aksesibilitas, tidak berpengaruh terhadap perkembangan tata guna lahan dinilai dari historis kelelawar sebagai nilai simbol di Kecamatan Lalabata Kabupaten Soppeng. Keberadaan habitat kelelawar sebagai icon atau brand Kabupaten Soppeng mengundang banyak kegiatan masyarakat yang berkembang di sekitarnya. Selain itu pola tata transportasi yang bersimpul pada area ini tidak mempengaruhi keberadaan habitat kelelawar.

4) Sarana dan prasarana

Diperoleh dari nilai sig $885>0,05$ maka variabel sarana dan prasarana tidak berpengaruh signifikan terhadap perkembangan tata guna lahan di tinjau dari historis kelelawar sebagi nilai simbol di Kecamatan Lalabata Kabupaten Soppeng. Menurut Nasution (2004) mengemukakan bahwa semakin baik sarana dan prasarana suatu wilayah maka akan berkembang wilayah tersebut. Hal ini bertentangan dengan hasil penelitian karena dari hasil analisis faktor sarana dan prasarana tidak berpengaruh terhadap perkembangan tata guna lahan di tinjau dari nilai historis kelelawar sebagai nilai simbol di Kecamatan Lalabata Kabupaten Soppeng.

5) Daya dukung lahan

Diperoleh dari nilai sig $885>0,05$ maka variabel daya dukung lahan tidak berpengaruh signifikan terhadap perkembangan tata guna lahan di tinjau dari historis kelelawar sebagi nilai simbol di Kecamatan Lalabata Kabupaten Soppeng. Menurut Sujarto (1999) sebagaimana yang diuraikan oleh Oktara (2011) bahwa terjadinya perkembangan/perubahan tata guna lahan yang disebabkan oleh kemampuan daya dukung lahan berpengaruh terhadap aktivitas atau pembangunan yang ada di atasnya sehingga akan menentukan jenis tata guna lahan yang di bolehkan. Sedangkan berdasarkan dari hasil penelitian hal ini "tidak sejalan" karena daya dukung lahan tidak mempengaruhi perkembangan tata guna lahan di Kecamatan Lalabata Kabupaten Soppeng.

Berdasarkan dari hasil penelitian, habitat kelelawar yang berada di perkotaan Watansoppeng merupakan faktor yang mempengaruhi perkembangan tata guna lahan di Kecamatan Lalabata Kabupaten Soppeng karena memiliki nilai historis dan kebudayaan yang tinggi bagi masyarakat di Kecamatan Lalabata Kabupaten Soppeng. Masyarakat lebih dominan untuk tidak membangun di sekitar habitat kelelawar yang berada di perkotaan Watansoppeng karena kelelawar adalah merupakan simbol atau ciri khas Kabupaten soppeng yang harus dilestarikan dan dilindungi. Masyarakat juga memilih untuk tidak membangun di sekitar habitat kelelawar karena adanya bangunan peninggalan sejarah yang harus dijaga dan dilindungi keberadaannya. Proses pembangunan tetap berorinetasi pada upaya menjaga kelestarian habitat kelelawar. Dampak dari adanya aktivitas manusia yang intensif yang dilakukan dalam proses tersebut dapat mempengaruhi fluktuasi ekosistem, keanekaragaman hayati dan respon dan ketahanan dari suatu spesies (Gámez-Virués et al, 2015 dalam Taradipha et al., 2018). Untuk mengintegrasikan antara pembangunan dan pelestarian habitat kelelawar yang merupakan ciri khas dari Kabupaten Soppeng perlu adanya konsep tata lingkungan dan kelelawar sebagai landmark Kabupaten Soppeng sehingga fungsi kawasan yang terdapat di sekitar habitat kelelawar tidak berubah serta dapat dimaksimalkan. Selanjutnya untuk mengintegrasikan pembangunan dan pelestarian habitat kelelawar yang ada di Kecamatan Lalabata Kabupaten Soppeng juga harus memperhatikan pusat aktivitas wisata atau rekreasi di perkotaan Watansoppeng.
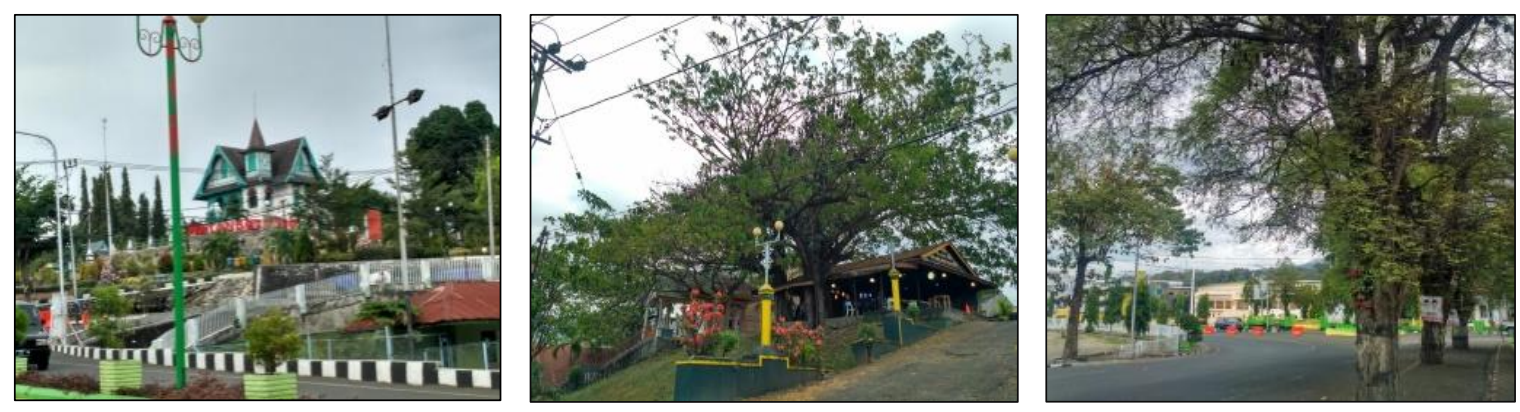

Gambar 1. Kenampakan kawasan perkotaan Watanasoppeng (Sumber: Dokumen Peneliti, 2019) 
Upaya untuk menjaga keberlangsungan habitat kelelawar juga dapat dilakukan dengan pengaturan tentang jenis-jenis kegiatan yang diperbolehkan di sekitar habitat kelelawar agar tidak terusik dengan berbagai kegiatan yang dilakukan. Ruang terbuka publik atau biasa disebut public space juga merupakan unsur penting dalam pengintegrasian antara pembangunan dan pelestarian habitat kelelawar agar masyarakat dapat berinteraksi dengan satwa tersebut. Dalam suatu wilayah perkotaan, empat fungsi utama ini dapat dikombinasikan sesuai dengan kebutuhan, kepentingan, dan keberlanjutan kota seperti perlindungan tata air, keseimbangan ekologi, dan konservasi hayati khususnya flora dan fauna endemic di wilayah tersebut (Imansari \& Khadiyanta, 2015). Keberadaan kelelawar di kawasan perkotaan Watansoppeng menjadi keunikan tersendiri sekaligus sebagai bentuk penguatan kearifan lokal. Kearifan lokal dapat menjadi salah satu aspek pertimbangan dalam pengembangan kawasan termasuk dalam pengembangan perkotaan (Surur et al., 2014).

\section{SIMPULAN}

Dari hasil penelitian yang dilakukan di kawasan habitat kelelawar yang terdapat di Kecamatan Lalabata Kabupaten Soppeng (pusat perkotaan Watansoppeng), dapat diketahui bahwa perkembangan perkotaan mengarah keluar atau membentuk pola linier mengikuti arah jalan sehingga perkotaan tidak terpusat di perkotaan Watansoppeng. Faktor yang berpengaruh dalam tata guna lahan di kawasan penelitian adalah penduduk. Hal ini didasarkan dari hasil analisis data melalui analisis regresi yang diperoleh yakni nilai sig $000<0,05$ untuk variabel penduduk yang berarti berpengaruh, sedangkan faktor lainnya memiliki nilai sig $>0,05$ yang berarti tidak berpengaruh. Arahan penata gunaan tanah dalam menjaga keberlanjutan habibat kelewar adalah dengan memaksimalkan potensi ruang terbuka hijau publik sebagai wujud interkasi antara penduduk lokal dengan kelelawar.

\section{DAFTAR PUSTAKA}

Aminah, S. (2015). Konflik dan kontestasi penataan ruang Kota Surabaya. MASYARAKAT: Jurnal Sosiolog, 59-79.

Amiuza, C. B., \& Ernawati, J. (2014). Karakter kota dalam persepsi masyarakat (Studi kasus kota pantai Probolinggo). Journal of Environmental Engineering and Sustainable Technology, 1(1), 33-39.

Eko, T., \& Rahayu, S. (2012). Perubahan penggunaan lahan dan kesesuaiannya terhadap RDTR di wilayah Peri-Urban (Studi kasus: Kecamatan Mlati). Jurnal Pembangunan Wilayab dan Kota, 8(4), 330-340.

Hasni. (2016). Hukum penataan ruang dan penatagunaan tanah edisi ketiga. Jakarta: PT. Raja Grafindo Persada.

Imansari, N., \& Khadiyanta, P. (2015). Penyediaan hutan kota dan taman kota sebagai Ruang Terbuka Hijau (RTH) publik menurut preferensi masyarakat di kawasan pusat Kota Tangerang. Jurnal Ruang, 1(3), 101-110.

Litiloly, M. K. (2019). Studi morfologi kawasan Kota Gede Yogayarta: Perkembangan pola kawasan Kotagede dan faktor-faktor yang mempengaruhinya. Jurnal Arsitektur Komposisi, 12(3), 211-224.

Nasution, Zulkifli. (2005). Evaluasi laban daerah tangkapan bujan Danau Toba sebagai dasar perencanaan tata guna lahan untuk pembangunan berkelanjutan. Pidato pengukuhan jabatan guru besar tetap dalam bidang ilmu survey tanah dan evaluasi lahan. Fakultas Pertanian Universitas Sumatra Utara.

Nugroho, A. C. (2009). Kampung kota sebagai sebuah titik tolak dalam membentuk urbanitas dan ruang kota berkelanjutan. Jurnal Rekayasa, 13(3), 209-218.

Oktora, Roni. (2011). Presepsi masyarakat terhadap pembangunan jalan lingkar utara Kota Solok Sumatera Barat. Tesis, tidak dipublikasikan. Semarang: Universitas Diponegoro.

Peraturan Daerah (Perda) No. 66 Tahun 2006 Tentang Pelestarian Kelewar di Kabupaten Soppeng. 
Piter, F., Tri, R. S., \& Irwan, L. (2015). Karakteristik populasi dan habitat Kelelawar Hipposideros cervinus (Sub ordo Microchiroptera) di Gua Bratus Kecamatan Air Besar Kabupaten Landak. Protobiont, 77-83.

Surur, F., Sitorus, S. R., \& Agusta, I. (2014). Pertimbangan Aspek sosial budaya dan kearifan lokal dalam pengembangan kawasan Danau Tempe Provinsi Sulawesi Selatan. Tataloka, 16(3), 168-180.

Sujarto, Djoko. (1999). Kota berkelanjutan. Bandung : Alumni.

Sutomo, Sugiono. 2009. Urbanisasi dan morfologi, proses perkembangan peradaban dan wadah ruang fisiknya : menuju ruang kehidupan yang manusiawi. Yogyakarta : Graha Ilmu.

Tallo, A. J., Pratiwi, Y., \& Astutik, I. (2014). Identifikasi pola morfologi kota (Studi kasus: sebagian Kecamatan Klojen, di Kota Malang). Jurnal Perencanaan Wilayah dan Kota, 25(3), 213-227.

Taradipha, M. R., Rushayati, S. B., \& Haneda, N. F. (2018). Karakteristik lingkungan terhadap komunitas serangga (Environmental characteristic of insect community). Journal of Natural Resources and Environmental Management, 9(2), 394-404.

Wahrudin, U., Atikah, S., Al Habibah, A., Paramita, Q. P., Tampubolon, H., Sugandi, D., \& Ridwana, R. (2019). Pemanfaatan Citra Landsat 8 untuk identifikasi sebaran kerapatan vegetasi di Pangandaran. Geodika: Jurnal Kajian Ilmu dan Pendidikan Geografi, 3(2), 90-101.

Wulandari, E., \& Aulia, F. (2018). Pengaruh morfologi kota terhadap ekologi perkampungan tradisional di Kota Banda Aceh, Indonesia. Jurnal Arsitektur Zonasi, 1(1), 45-54.

Yusuf, B. (2017). Lingkungan hidup dan manusia (Kajian falsafah kalam). Jurnal Aqidah-Ta, 3(2), 99-122. 